\title{
Theories of Collective Action and the Iranian Revolution
}

\author{
Misagh Parsa \\ University of Michigan
}

Most analyses of the collective actions that led to the Iranian revolution rest upon one of two classical models: social breakdown or social movement. These explanations emphasize such factors as the politicization of recently uprooted migrants, the growth of a new middle class opposing autocracy, the authority of the clergy, and specific aspects of Shiite Islam. Conflicts of interest, capacity for mobilization, coalition formation, and the structure of opportunities that shaped the collective actions of various groups and classes are ignored or downplayed. This paper argues that mobilization and collective action against the monarchy resulted from the adverse effects of state development policies on bazaaris, industrial workers, white-collar employees, and professionals. Bazaaris' mobilization provided an opportunity for other social groups and classes to oppose the government. A coalition of disparate interests, led by Ayatollah Khomeini, brought down the monarchy.

\begin{abstract}
Iran's two major twentieth-century revolutions, and especially the second, appear so aberrant. They do not fit very closely widespread ideas of what modern revolutions should be like. Yet there is no doubt that the Islamic revolution in 1978-79 provided a thoroughgoing overtbrow of the old political, social, and ideological order (Keddie, 1983:580).
\end{abstract}

Although many observers have argued that Iran's most recent revolution departed somewhat from previous patterns of revolutionary mobilization and outcome, most analysts have attempted to explain the collective actions that led to the overthrow of the monarchy by using one of two classical theoretical models: social breakdown and social move-

\footnotetext{
- I wish to thank William Gamson, Max Heirich, Howard Kimeldorf, Aldon Morris, Susan Rosales Nelson, Jeffery Paige, Thomas Weisskopf, Mayer Zald, and anonymous reviewers of Sociological Forum for their helpful comments on an earlier version of this paper. I especially wish to thank Charles Tilly for his excellent advice throughout the preparation of this paper.
}

(C) 1988 by the Eastern Sociological Society. All rights reserved. $0884-8971 / 88 / 0301-0044 \$ 1.50$ 
ment. Generally speaking, the social breakdown model emphasizes those processes that culminate in the dissolution of traditional social structures, norms, and values. Large-scale social transformations such as industrialization, commercialization, and urbanization are hypothesized to generate social disorganization and associated strains, frustrations, anxieties, disorientations, and grievances, which in turn may explode in collective violence and civil disorder (Johnson, 1966; Smelser, 1962, 1966). One variation of this model emphasizes social mobilization and the resultant rise of new needs and demands, which in turn may engender political tension (Deutsch, 1961). Another variation stresses the destabilizing effects of rapid social and economic change and the resultant disjunction between political and economic development, which may produce disorder and violence (Huntington, 1968). In contrast, the social movement model follows Weber's emphasis on ideational factors and authority figures. Social movements are founded upon "the conscious volition, normative commitment to . . . aims or beliefs, and active participation on the part of followers or members" (Wilkinson, 1971:27). According to this view, groups develop new collective definitions of the world and of themselves that elaborate new goals, norms of behavior, and justifications for the power of authorities.

I intend to show that both these models are insufficient to explain the collective actions that brought down the Iranian monarchy. Any explanation of the revolutionary conflicts in Iran must take into account variables emphasized by resource mobilization theory (Tilly, 1978): conflicts of interests, capacity for mobilization, opportunities for collective action, and formation of coalitions. A full explanation must also analyze the structural vulnerabilities of the Pahlavi state. In this article, I present a critique of social breakdown and social movement analyses as they have been applied to the Iranian case. I then offer an alternative explanation of the mobilization and collective actions in the political conflicts that culminated in the Iranian revolution.

\section{THE SOCIAL. BREAKDOWN MODEL.}

The literature on the Iranian political conflicts is vast and continues to grow. The following discussion will consider only those works that deal specifically with the revolution and approximate one of these two schools of thought. The social breakdown model, in one form or another, has been most commonly used to analyze the collective actions that overthrew the Iranian monarchy. Majid Tehranian, for example, has argued that modernization entailed a triple curse for Iran. In the first place, modernization arrived in Iran in the form of Westernization, which meant the "uprooting of indigenous social, economic, political, educational, and legal institutions in favor of their Western counterparts. The 
cohesion and coherence of a traditional corporate society was thus gradually replaced by the tensions and contradictions of a modernizing society with few, if any, indigenous modernizing institutions" (1980:6). Secondly, Westernization bred a political and cultural elite whose habits, tastes, and life-style differed sharply from the rest of the population, thereby creating deep social divisions. Finally, modernization was accompanied by economic growth, which brought with it rapid urbanization, social mobilization, and the unfolding of an acquisitive consumer society. "The social system was not able, however, to absorb the disintegrating effects of all these forces which were unleashed, particularly after the so-called 'White Revolution' of the early 1960s. What seemed to many foreign observers as a showcase of enlightened dictatorship and development was in fact the making of a national tragedy" (1980:10).

Another aspect of the breakdown model has been stressed by Jerrold Green (1980), who argued that "rapid socioeconomic development gave rise to demands for popular participation" (1980:32). Because the Shah ignored these demands, he forced those who sought participation to use means outside the existing system. According to Green, the Shah wanted to develop Iran economically, but was unwilling to modernize the country's political system. This contradiction lay at the root of the revolution. The Shah's policies increased the rate of literacy, educational attainment, urbanization, and exposure to mass media. The resulting social mobilization led to the rapid proliferation of ideas and to politicization. As Green suggests, "such ideas are not necessarily dangerous, but given the absence of communication between the Crown and the Iranian people, and the denial of political participation, they ultimately proved to be fatal" (1980:38-39). The outcome was societal instability and eventual breakdown because the regime was unable or unwilling to permit greater participation in the political sphere.

More recently, Green has argued that the revolution derived from a combination of additional crucial factors, the first of which was the Shah's unwillingness to employ coercion to repress middle class professionals who demanded political liberalization (1986:129-130). Reduced repression was contrary to the Shah's historical policies and was due in part to international pressures to liberalize, as well as to the Shah's cancer and the listlessness that resulted from his chemotherapy. It was also possible the Shah refrained from repression to facilitate his son's succession to the throne. A second factor contributing to the revolution was the polarization of the population against the regime. Thousands of mullahs linked through mosque networks politicized recent urban migrants in that direction. Finally, several specific repressive incidents in which hundreds of people were killed by the regime enhanced people's unity in the struggle against the Shah.

According to Amin Saikal (1980:203-204), the Shah's dual objec- 
tives of strengthening the monarchy and transforming Iran into a modern pro-Western state were mutually incompatible and brought about his downfall. To strengthen his position, the Shah attempted to make himself indispensable by centralizing power as much as possible. In the 1970s, he embarked upon a policy of harsh political repression and manipulation of economic and social processes. However, his program of socioeconomic development unleashed forces contradictory to centralized rule, including growing political and economic decentralization, public participation, and individual initiative. In 1977, when the Shah became aware of the dilemma, he initiated a policy of gradual "liberalization" that proved too slow and too late, and as a consequence, he was forced from the throne.

Similarly, Nasser Momayezi (1986) has argued that Iran's socioeconomic development increased the rate of literacy, exposed a growing number of people to the mass media, and inevitably fostered the growth of a new middle class that eventually constituted more than 25 percent of the population. These developments generated new aspirations for political participation. However, "Iran's formal political structure was not developing the requisite capacities to deal with the demand for political involvement. The resulting unevenness of development among socioeconomic and political sectors, and the degree and pattern of imbalance, had consequences for domestic instability in Iran" (1986:77). The new middle class acquired skills and talents through the educational system and was eager for political influence. This group played the most active part during the revolution.

Nikki Keddie (1983) has applied theories developed by Davies (1962) and Marx to the Iranian case. She maintains that Iran's prerevolutionary experience of the 1970 s fits neatly into Davies's J-curve, which predicted revolution when rapid economic growth is followed by a sharp downswing. Increased oil revenues boosted investments, elevated inflation, intensified shortages, swelled urban migration, and aggravated hardship and popular discontent. To cool down the economy and curb inflation, the government cut back on construction, which especially affected recent urban migrants, and reduced payments to clergy. These groups joined with intellectuals and a large educated class to provide "the backbone of a new mass politics." Applying the "Marxist formula," Keddie maintains that "revolution occurs whenever the relations of production . . . have changed beyond the ability of the old forms of political power and state organization to subsume the new economic order" $(1983: 588,591)$. She identifies the main conflict as one between major classes and the autocracy. The modernization process had created a sizable, well-educated stratum of bureaucrats and technocrats, while many industrialists had sprung from the bazaar. Along with workers, who felt grievances over the growing privileges of foreigners, this relatively 
privileged new middle class, the upper class, and the rich bazaaris (merchants, shopkeepers, and artisans) were discontented. "Their economic futures were often determined arbitrarily and irrationally by fiat from the top, while they were denied all real participation in self-government and the political process. Both the success and the failures of modernization put different classes, from the urban poor to the new middle classes, at odds with the autocratic government" (1983:592). This analysis fits precisely into Huntington's model of political conflict.

A number of analysts have invoked the theory of rising expectations to explain the Iranian revolution. John D. Stempel has maintained that increased oil revenues led the government to implement a rapid development policy. Coupled with the Shah's constant claim that he was building "The Great Society," this policy encouraged Iranians to expect an improved quality of life. However, improved economic conditions did not reach most Iranians who instead "looked on with growing envy, improving their lifestyle only slightly. The shortfall between expectation and results produced the political reaction that began to spell trouble for the government" (Stempel, 1981:9). Gary Sick has argued that revolutions seem to occur in societies "when general expectations of improved political, economic or social conditions are thwarted or interrupted" (1985:159). Despite a long period of economic growth in the decade following the White Revolution, Iran's political system failed to keep pace with economic development, and most social groups were excluded from the political process. As long as the general growth benefited most of the population, the system functioned. However, by the mid-1970s, the boom faltered, and distortions emerged in every economic sector. Once "popular discontent began seething beneath the surface, Iranians had no outlet to express their grievances, which began to build to the point of explosion" (Sick, 1985:160). In the absence of political channels people turned to the mosque, which Sick correctly identified as the only institution not totally dominated by the Shah. Similar analyses based on rising expectations have been made by Thomas Walton (1980) and Daniel Pipes (1983).

\section{THE SOCIAL MOVEMENT MODEL}

A second line of explanation for the Iranian revolution follows the social movement model. In contrast to breakdown theories, which identify the erosion of traditional values and structures as the fundamental cause of the revolution, the social movement model assigns primary importance to religious values and the authority of the clergy. Shahrough Akhavi $(1980,1983)$ has identified several central elements of Shiism: the principle of clerical fatwa, or the power to command followers to 
take particular action; Shiite martyrdom, which emulated the martyrdom of Imam Husayn; and the desire to maintain the integrity of the Islamic community. Under the Shah, political corporatism and the regime's policies of economic development caused many social groups, including tribal groups, poor peasants, the petite bourgeoisie, and the urban poor, to decline. Middle class defection away from the Shah during the economic crisis of the mid-1970s, Akhavi agrees with other observers, was largely a reaction against a sudden reversal in the general prosperity brought by oil. Most importantly, the Shah's attack upon the social, economic, and educational position of the clergy undermined the integrity of the Islamic community and consequently earned clerical disapproval and opposition. This attack might have succeeded had the Shah not also appropriated the "cultural symbols which in the past had been so vital in inculcating among Iranians a sense of self, an explanation of the cosmos and social reality" (Akhavi, 1980:203). Through fatwa, the Islamic clergy withheld legitimacy from the Shah and his rule. Symbols of martyrom expressed in passion plays during the revolution mobilized Shiites against the regime. In combination, these Shiite features generated the collective actions that eventually overthrew the monarchy.

Said Arjomand $(1981,1986)$ has presented an analysis that combines elements of both breakdown and social movement models, but places greater emphasis upon the latter. He assigns only a minor role to class interest in the revolution (1986:400), stressing instead ideology, tradition, and culture. According to Arjomand, the monarchy was vulnerable because it was so highly focused and dependent upon a single person. The process of mobilization can be understood in terms of rapid social change that led to dislocation, "normative disturbance," and disorientation (1986:383). A "fundamental disorientation and anomie more than superficial short-run frustration of material expectation" (1986:397) fueled the widespread desire for revolutionary change. To reintegrate themselves into the community, dislocated individuals and groupsspecifically recent migrants and the urban poor-embraced an Islamic revival from the mid-1960s onward. The new middle class also embraced this religious revival, impelled by the "alienating modern world" to "consolidate their attachment to the Islamic tradition and . . . reaffirm their collective cultural identity" (1981:312). At the same time, the Shah's regime systematically undermined the position of the clergy, who eventually spearheaded a "traditionalist revolution." In assuming the leadership of the revolution, the clergy benefited from the long-standing historical alliance between the bazaar and the mosque. The basis of this alliance was an "intense rejection of foreign and antireligious cultural influences on the part of mullahs and the merchants of the bazaar" (1986:397). Finally, Arjomand argues that specific features of Shiite Is- 
lam such as the Shiite theodicy of suffering, the martyrdom of Imam Husayn, and Shiite millenarianism enabled the clergy to harness traditional religious sentiments in the struggle against the regime.

Although Theda Skocpol is not a social movement theorist, her analysis of the Iranian collective actions falls within this category. In discussing Iran (1982), she departs from her earlier structural theory of revolution (1979). In that previous work, she refuted a model of revolution based on ideological causation, but the Iranian case, she now argues, was unique and did follow a model of purposive action. More specifically, she elaborates on the possible role of ideas and culture in shaping political action (1982:268). The Iranian monarchy, like ancient regimes in France, Russia, and China, was fundamentally weak because the Shah did not rule in alliance with an independent social class. In addition, his program of crash industrialization and military modernization experienced setbacks as a result of fluctuations in the world market, generating universal resentment against him. Despite urban discontent, the Shah, according to Skocpol, should have been able to retain power due to the munificent wealth and ominous repressive power at his disposal. Ultimately, the force behind the Shah's downfall lay in "traditional centers of urban communal life and in networks of Islamic communication and leadership" (1982:271), that is, in bazaars and mosques. In Skocpol's view, the clergy were the leaders of the bazaar, which connected artisans and merchants to agricultural producers. By the mid1970 s, "the Shah seemed determined to attack the traditional aspects of bazaar life" (1982:272) by controlling self-regulating merchants' councils, extending state involvement in trade, and launching an "anticorruption" campaign against alleged profiteering in the bazaar. These activities coincided with the Shah's steady efforts to exclude the Islamic clergy from educational, legal, and welfare activities. The clergy, who, trained to interpret Islamic law for believers, could claim, "as well or better than the monarchs, to represent authentically the will of the Hidden Imam" (1982:273), provided leadership, networks, and symbols of communication against the Shah during the revolution. Even more important in sustaining the struggles, Skocpol argues, was the Shiite belief system. In particular, the story of Husayn's willing martyrdom in the just cause of resisting the usurper caliph, Yazid, inspired devout Shites to continue their opposition against the Shah in the face of repression and death.

\section{CRITIQUE}

These scholars have enhanced our understanding of the Iranian revolution by exploring various reasons for the rise of opposition to the Shah during 1977-1979. Although these analysts have correctly pointed 
out many shortcomings of the Pahlavi regime, their theoretical explanations are unsatisfactory. In the following discussion, I shall offer both theoretical arguments and empirical evidence to illuminate some of the problems in these explanations. Because the works reviewed above all attempt to explain popular mobilization and collective actions, I will confine most of my analysis to those processes.

\section{Breakdown Theories}

Breakdown theories maintain that large-scale social transformations such as urbanization are associated with rising collective action. Such transformations uproot great numbers of individuals who experience anomie and are likely to engage in antisocial acts. However, although large-scale transformations may indeed generate anxiety, frustration, and disorientation, they do not automatically lead to collective action or culminate in social revolutions. In the first place, rising stress and strain do not necessarily generate the solidarity structures and resources required for collective action. Hence, although uprooted populations may have many grievances, they are unlikely to possess sufficient solidarity structures and networks to act collectively. The very experience of being uprooted is likely to reduce their capacity for collective action by dissolving existing solidarity structures (Tilly, Tilly, and Tilly, 1975). Second, even if uprooted populations were to engage in collective action, they would be more likely to attack other social groups such as landlords or merchants through rent strikes or food riots, rather than the state. After all, why should uprooted and anomic individuals suddenly become politicized and attack the government, which possesses great resources to repress the unruly? The mere fact of recent migration to urban areas is insufficient to mobilize migrants to act collectively against the state.

Empirical data on the participation of recent migrants in the antigovernment protests is extremely difficult to obtain. The sparse evidence that is available does not support the breakdown model. A conflict between the government and recent migrants erupted in the summer of 1977 when the regime began demolishing shantytowns around Tehran. Although established, urbanized groups residing in these areas were able to mobilize and act collectively on some occasions, recent migrants living in shantytowns tended to abstain from collective action, preferring to obtain housing permits from the government and thus solve their problems individually. This course of action was consistent with migrants' general view of authority and of the Shah. Like nineteenth-century Russian peasants, Iranian peasant migrants evidently believed that the Shah was simply unaware of their suffering at the hands of government officials. Had he known of their plight, he would doubtless have 
acted on their behalf. Some simply expressed their hope that it was time for God to act or avenge them against their oppressors (Organization, 1978:4-5).

During the later revolutionary uprising, many squatters still apparently did not act collectively against the regime. As late as December 4,1978 , onc squatter told a New York Times reporter that he was obliged to work from 6:00 A.M. to 7:00 P.M. and had no time to demonstrate, but he knew that "things will get better once the king goes." On January 14, 1979, less than a month before the monarchy fell, the Washington Post quoted another squatter as saying, "The demonstrations are all crap. No one has done anything for us except when we stopped a car heading elsewhere that was distributing clothes in Khomeini's name. We have heard about the demonstrations, but we don't take part; to demonstrate you have to have a full stomach." The man added, "Whoever gives us bread and work, we will be with him."

In the more formal industrial sector, recent migrants appear to have been the least inclined to join strikes. For example, recent migrants employed at Isfahan Steel lacked the politicization of urbanized workers and partly caused the failure of the steelworkers' strike in the fall of 1978 (Zob-e Ahan,' 1978:16-17). Their politicization was inhibited by the fact that some migrants worked only part-time in the city because they had agrarian income in addition. They also had the option of returning to their villages if urban employment proved unsatisfactory. In sum, one cannot conclude that migrants were crucial in initiating the conflicts or were essential to the overthrow of the regime. During the final weeks of the revolution, some urban migrants, like a segment of the peasantry, perhaps became politicized and joined antigovernment demonstrations. But the available evidence does not support the assertion that recent migrants were highly politicized and especially active in antigovernment protests throughout the political conflicts.

Another version of the breakdown theory emphasizes the disjunction between socioeconomic and political development. According to this perspective, the Shah's development policies generated a new middle class that demanded political freedom and democracy. Some breakdown theorists point to the National Front, the Lawyers' Association, and the Writers' Association as examples of middle-class organizations that began demanding political freedom in the summer of 1977. This theory fails, however, to account for the emergence of vigorous political

'Zob-e Aban: Tablity Bar Eatesab-e Mebr Mabe 1357 is a pamphlet presenting an analysis of the steel mill strike of October 1978, written by a group of steel employees. In this article, citations for pamphlets, newsletters, and newspapers include the date of the issue and page numbers if available; no further bibliographical references are given for these sources. 
conflicts in Iran in the absence of a sizable new middle class during the Constitutional Revolution of 1906-1909, or during the 1940s and the 1950s. Without doubt, the new middle class expanded during Iran's rapid economic development of the 1960s and 1970s. It should be noted, though, that the leading figures in reformist organizations had been politically active since the 1950 s and 1960 s and were not part of the newly expanding middle class. Even if we assume that these organizations represented the new middle class, this class did not respond to attempts these organizations made to mount opposition against the government. This class had little capacity for political action, lacking the requisite solidarity structures and organizations to act collectively. White-collar employees and professionals refrained from entering the conflict for more than a year after reformist political organizations had initiated opposition activities. When they finally joined the conflicts, most initially demanded economic rather than political changes. In short, the new middle class cannot be said to have instigated collective action against the state; rather, they joined in struggles that had been launched by others.

Theoretical explanations that invoke rising expectations or Davies's $\mathrm{J}$-curve argue that when oil revenues suddenly dropped, satisfaction, which had risen along with expectations as Iran's economic condition improved, rapidly diminished, leading to collective action and revolution. These theories ignore several important components of collective action, including the differential effects of economic development, the capacity of actors, and the targets of action. First, although higher oil revenues undoubtedly improved the satisfaction of some social groups, that experience cannot be generalized to the country as a whole. In highly stratified societies, economic improvements are unlikely to benefit all social classes or to benefit them equally. Although land reform raised peasants' expectations and temporarily improved conditions for some of them, the economic growth of the 1970 s adversely affected the income and expectations of the vast majority of the rural population. In the urban areas, although Iranian industrialists accumulated huge sums of capital, most industrial workers were adversely affected by higher oil revenues, which boosted inflation. Second, in order for groups to respond with collective action when their established rights and interests are violated, they must possess sufficient solidarity structures and resources. The J-curve and the theory of rising expectations assume the existence of both solidarity and organization, a dubious assumption, and hence are inadequate to explain mobilization and collective action. Despite the deterioration of agricultural conditions, the peasantry took little part in the collective actions of revolutionary conflicts. Not until the final days of the revolution did a segment of the peasanty join in the antigovernment protests, and their actions were inconsequential. Similarly, industrial workers lacked the capacity and organization to mobi- 
lize and initiate collective action to obtain a greater share of the increased national resources. Thus they did not engage in any collective action in the early stage of the conflicts, despite declining satisfaction, or "frustration" of their "expectations." In contrast, bazaaris did act collectively from the early period, partly because they possessed greater solidarity structures and resources.

Nor, finally, do these theories specify the target of collective action. Reduced satisfaction does not necessarily lead to an assault on the state. A natural disaster, for example, might drastically reduce human satisfaction but may not generate collective action, let alone a challenge to the state. Even when reduced satisfaction is attributed to social causes, adversely affected groups may turn upon a class or group deemed responsible. In such cases the dominant class or a minority group, rather than the state, may become the target of attack. During the 1930s, the Great Depression in the United States did not prompt an offensive against the state. Instead, industrial workers acted against their employers to gain certain rights, including the recognition of labor unions for collective bargaining (Parsa, 1985). In contrast, Iranian bazaaris acted against the state, which they identified as the source of conflict and injustice. Had the Iranian economic decline been perpetrated by the market mechanism, bazaaris might have ended up blaming themselves, as did some American businessmen during the depression. For all these reasons, the J-curve and the theory of rising expectations provide at best only a partial explanation of the Iranian revolution.

\section{Social Movement Theories}

Unlike social breakdown theories, social movement theories of the Iranian revolution focus primarily on the importance of specific Shiite beliefs and the clergy's legitimate authority in mobilizing the Iranian people. The Shiite culture of martyrdom and the desire to maintain the integrity of the Islamic community, combined with clerical authority and the power to issue fatwa, have been advanced as primary factors responsible for the overthrow of the monarchy. These explanations tend to be circular accounts that begin with the outcome of the revolution, that is, clerical victory or the establishment of the Islamic Republic, and work backward to rationalize it. Such analyses obscure the process that led to those outcomes.

Perhaps cultural and religious symbols play a role in political mobilization. Their part must be considered within the larger social and economic framework, however. In 1963, when most clergy opposed the government reforms as anti-Islamic, the authority of the clergy and appeals to Shiite martyrdom were insufficient to mobilize the vast majority of Iranians. Protests of segments of the population in a few major cities 
lasted only for three days, after which time government repression brought them to an end. It is not the case, as Skocpol thinks, that urban Iranians constituted traditional communities that always followed their religious leaders or that Iranians wanted to maintain the integrity of their Islamic communities. The fact that they ultimately formed a coalition against the monarchy does not prove that they were composed of such communities. Indeed Iranian society had been divided along class lines long before the 1979 revolution. Even bazaaris did not form communities, because, as I will show, they were economically and politically diverse. More importantly, the different groups and classes that opposed the government had different resources and solidarities, as well as conflicts and grievances, and therefore entered into active opposition at different times (Abrahamian, 1982; Ashraf and Banuazizi, 1985). Finally, clerical rule has not resolved many of the prerevolutionary conflicts; massive conflicts and violence have continued after the revolution (Parsa, 1986). Analyses based on Shiite martyrdom or analyses that depict Iranian society as composed of traditional communities cannot explain these postrevolutionary conflicts.

Social movement analysts also stress the significance of clerical authority. They tend to portray the clergy as a homogenous social stratum, pursuing a united politics. In fact, the clergy were far from unified throughout the 1970s. Religious authorities represented a spectrum of political views: some supported the monarchy, others opposed it, while the vast majority were nonpolitical. The preeminent clerics residing in Iran were among the nonpolitical camp. For example, the highest religious leader in Tehran, Ayatollah Khonsari, asked bazaaris not to close down when they were preparing for a strike to protest the government massacre of clerical students in Qom in January 1978 (Freedom Movement, Vol. I:127). In response to this massacre, preeminent clerics met but failed to produce a joint statement and made no recommendation to the Qom bazaar already on strike. One of them argued that the bazaars should reopen, angering the bazaaris (Freedom Movement, Vol. I:52). More importantly, the religious leaders rejected a popular request for a nationwide strike (Payam-e Mujahed, ${ }^{2}$ \#53). As protests spread, these clerics chose a relatively moderate approach, asking that the constitution be implemented as written and not abolished. They never called for the establishment of an Islamic Republic. They consistently discouraged radical confrontation and never exhorted their followers to become martyrs (Zamimeh-e Khabar Nameh, 1978, \#16:3). In fact, in mid-August 1978 , they avoided requesting mourning ceremonies ex-

\footnotetext{
${ }^{2}$ Payam-e Mujahed was a weekly publication of an Islamic group in the United States. Zamimeb-e Khabar Nameh, also cited in this paragraph, is a compilation of newsletters published by the National Front in 1977 and 1978.
} 
pressly because previous mourning observances had led to additional deaths.

Divisions also existed within the clerical minority who were political. Although a small fraction ${ }^{3}$ had long supported the Shah even during the 1963 conflicts (Akhavi, 1980), most opposed the Shah. Many followed Ayatollah Khomeini's line and were consistently repressed by the regime. For years, this segment of the clergy lacked the capacity to mobilize the population, partly because many well-known clerical activists had been jailed. Furthermore, pro-Khomeini clerics were mostly concentrated in a few religious centers and large cities, rather than distributed evenly throughout the country. Fully one-quarter of all clerical arrests took place in the religious center of Qom, while an additional 45 percent occurred in seven other cities. ${ }^{4}$ Despite uneven distribution, this faction of the clergy was able to attain a central position in the revolutionary conflict due to a combination of bazaari conflicts and the dynamics of state policies. Bazaari mobilization against the government provided an opportunity for these clerics to oppose the regime. With the reforms introduced in the fall of 1978 , this faction's capacity to act was enhanced by the cessation of clerical arrests and the release of virtually all jailed clerics.

It is important to recognize that bazaari conflicts and mobilization did not grow out of a clash between religious traditionalism and modernization. Although most bazaaris have indeed been religious and some paid religious taxes, their mobilization and collective actions have not always followed clerical leadership. Rather, their conflicts can better be explained by a combination of their economic interest, their capacity to organize for collective action, and their opportunity for mobilization, as a brief review of clerical and bazaari politics will illustrate.

\section{COLLECTIVE ACTION AND CONFLICTS 1950-1975}

In the early 1950 s, intense political conflicts, in which all major social groups and classes took sides, broke out between royalists and nationalist supporters of prime minister Dr. Mosaddegh. During these

\footnotetext{
${ }^{3}$ Approximately one hundred of these clerics were defrocked following the revolution; some of them were imprisoned, others exiled, and a few were executed. Authorities stated that the remainder have promised not to oppose the Islamic Republic (Kayban, 1981: May 27).

${ }^{4}$ Data on arrests of opposition clerics during the first nine months of their protests indicate that roughly 25 percent came from Qom, 13 percent from Tehran, 7 percent each from Mashhad and Hamedan, 5 percent each from Isfahan and Semnan, 4 percent from Shiraz, 4 percent from Rezaieh, and the rest from other cities. Arrests do not provide a complete indication of the distribution of radical clergy for many doubtless avoided arrest by moving underground. Living clandestinely, however, would have limited their effectiveness in mobilizing the opposition.
} 
conflicts, the politics and collective actions of bazaaris sharply diverged from those of most clergy. The conservative clergy, led by the country's preeminent cleric Ayatollah Boroujerdi, threw their support behind the Shah, arguing that Mosaddegh would lead the nation to communism. When oil was nationalized, these clerics and royalist members of the Majlis, or parliament, demonstrated in the Qom seminary, rejecting nationalization as a violation of property and as contrary to the laws of Islam (Nategh, 1982). In July 1952, during the conflict between Mosaddegh and the Shah over control of the army, the preeminent clerics of Qom sent their representative to Tehran to express support for the Shah (Nategh, 1982). When the monarch fled the country on August 16,1953 , Boroujerdi sent him a telegram asking him to return to preserve the nation, Islam, and the country's security. He and other highranking clerics in Qom held prayer sessions for the Shah's return (Jazani, 1979:139).

During the economic and political crisis that followed the nationalization of oil, most politically active clerics who had supported Mosaddegh left the nationalist camp and instead forged an alliance with the royalists. Among those who deserted the prime minister for the monarchy was Ayatollah Kashani, influential speaker of the Majlis in 1952 and 1953. He attempted to obstruct the passage of Mosaddegh's policies, charging that the prime minister had worsened economic conditions, violated the constitution, and was ruling the country in a dictatorial fashion. When Mosaddegh requested an extension of his emergency powers to resolve the country's crisis, Kashani refused to go along. Kashani refused to convene the Majlis to pass the report of the Eight-Member Committee designed to curb the monarch's power. Kashani opposed Mosaddegh's attempt to dissolve parliament by a popular referendum, labeling it illegal and dictatorial. Two days before the voting, Kashani led the right-wing opposition in a call to boycott the referendum (Ettelaat, ${ }^{5}$ 1953: August 1). Ayatollah Behbahani also consistently opposed Mosaddegh and supported the royalist position. During the coup d'état that removed the prime minister, Ayatollah Behbahani organized hooligans who, along with the army, looted National Front headquarters, the homes of the prime minister's supporters, and even the house of Mosaddegh himself.

When the majority of the clergy broke away from Mosaddegh, most bazaaris, organized in an independent guild called the Society of Tehran Bazaar Merchants, Shopkeepers, and Artisans (STBMSA), continued to support the prime minister. The bazaaris' economic position had been adversely affected by the large stock of imported goods after World War II and the economic recession that lasted from 1947 until 1952, which

${ }^{5}$ Ettelaat is an Iranian national newspaper. 


\section{Sociological Forum}

caused bankruptcies among merchants and small producers. Bazaaris blamed their plight on royalist policies and therefore supported Mosaddegh's nationalist government and demonstrated their support on crucial occasions. When Mosaddegh's government lacked sufficient revenue to pay government employees, merchants and shopkeepers lined up to buy special government bonds issued to ease the financial crisis. On July 17, 1952, when the prime minister resigned to protest the Shah's control over the army, Tehran bazaaris immediately struck and took to the streets in anti-Shah protests. Bazaaris elsewhere soon followed suit, closing their shops and holding sit-ins. On July 21 , bazaaris across the country demonstrated in response to a call by the National Front to support the prime minister, thus forcing the Shah to reinstate him. On that day eight hundred people were killed or injured in Tehran by the army. When Ayatollah Kashani and other clerics broke with Mosaddegh's National Front, the STBMSA continued to back the prime minister. They condemned Mosaddegh's opponents and demanded approval of the Eight-Member Committee's recommendation to curb the power of the Shah (Ettelaat, 1953: April 14). On this occasion, bazaaris demonstrated in overwhelming numbers in support of Mosaddegh (New York Times, 1953: April 16). On the first anniversary of the July 21 massacre, bazaaris throughout the country again closed down to attend pro-Mosaddegh rallies (Ettelaat, 1953: July 23). Even in the religious center of Qom, shopkeepers struck in support of Mosaddegh (Ettelaat, 1953: July 14). When Mosaddegh called for the referendum to dismiss parliament, bazaaris shut down their businesses to indicate support for him, despite a clerical boycott of the referendum. Industrial workers, organized primarily by the Tudeh Party, and white-collar employees also supported Mosaddegh during these conflicts. The referendum passed overwhelmingly, with 2,043,380 nationwide voting to dismiss parliament and only 1,207 voting to retain it (Ettelaat, 1953: August 15), and the Shah was obliged to dissolve the Majlis and order new parliamentary elections.

Following a failed coup d'état organized by the monarch against the prime minister, bazaaris rallied in large numbers to condemn the Shah, who fled the country. When a second coup finally ousted Mosaddegh three days later, bazaaris struck in protest (New York Times, 1953: August 21, 22). Despite assurances by the government that they would not be arrested nor their shops attacked, bazaaris refused to reopen out of loyalty to the prime minister. Colonel Dadsetan, military governor of Tehran, publicly complained that merchants declined to resume business (Ettelaat, 1953: August 23). Finally, the government forced them to reopen under duress (New York Times, 1953: August 25), and General Zahedi threatened to destroy the roof of the Tehran bazaar if the strikes were repeated (Binder, 1962:295).

A second round of political conflicts erupted in 1963 when the 
Shah introduced a series of reforms. The clergy led protests during the Shiite mourning ceremonies. Ayatollah Khomeini was the most outspoken opponent of the reforms, denouncing what he considered the regime's attacks on Islam and the clergy. Khomeini condemned the referendum held by the Shah to approve his reforms as against the interests of the Iranian people. Khomeini was arrested on June 5, 1963, and within a few hours, protests had broken out in Tehran, Qom, Mashhad, Isfahan, Shiraz, Tabriz, and Kashan. The bazaar in Tehran did not close down immediately upon the spread of the news. When demonstrators entered Tehran's central bazaar, however, merchants and shopkeepers shut their shops and joined them. Once shooting began, bazaaris retreated after suffering only a few casualties. In much of the rest of the country, shopkeepers and merchants refrained from antigovernment protests, in sharp contrast to their active support of Prime Minister Mosaddegh a decade earlier.

Bazaari opposition or lack of opposition to the government can be explained in terms of a combination of their economic interests, their lack of autonomous organization, and their opportunity for action. Bazaaris had supported Mosaddegh's nationalistic economic policies designed to halt growing international penetration of Iranian markets. Following the coup d'état, bazaari interests were adversely affected by the Shah's economic program, which encouraged foreign imports and the development of modern banking and industries. The economic position of shopkeepers and artisans was further undermined by two years of recession resulting from the imposition of a stabilization program recommended by the International Monetary Fund. Bankruptcies began to occur throughout the bazaars (Ettelaat, 1961: May 7), and bazaaris complained that the government did nothing to promote commerce (Ettelaat, 1963: May 21). Shopkeepers and artisans also protested a taxation scheme designed in 1961 by their guilds, objecting that guild leaders paid little taxes themselves and shifted the burden to poorer segments of the bazaar (Ettelaat, 1961: April 30). In protest, bazaaris refused to pay taxes for more than two years until the government began an investigation. In April 1963, investigators uncovered 300,000 cases of refusal to pay taxes in Tehran alone, most of which involved small shopkeepers and artisans (Ettelaat, 1963: May 19).

Although their economic interests were adversely affected by the government, bazaaris lacked both leadership and cohesive organizations to mobilize for unified collective action. Since the Mosaddegh period when they repeatedly issued statements and called for direct action, bazaaris had lost their capacity for mobilization. The primary reason for their inaction was repression. Bazaari leadership was weakened by the imprisonment of leaders of the second National Front (Ettelaat, 1963: January 24) and by the banning of the independent STBMSA. The new 
Merchants' Guild, founded after the coup d'état, was controlled by the government. Shopkeepers in central bazaars of large cities participated in the demonstration of June 5, 1963, because their bazaars were geographically concentrated, providing networks and facilitating communication. Clerical opposition to the regime provided an opportunity for these bazaaris to act collectively. Lack of organization, however, prevented many Tehran shopkeepers outside the central bazaar from taking part in the protests, and as a result, some stores were smashed and even looted (Ettelaat, 1963: June 6; New York Times, 1963: June 9; Christian Science Monitor, 1963: June 6). Significantly, white-collar employees, professionals, and industrial workers, especially oil workers who had played a crucial role during the nationalization strikes, as well as peasants, who welcomed the land offered by the government, did not join the antigovernment demonstrations.

On June 5, 1975, the twelfth anniversary of the 1963 uprising following the arrest of Ayatollah Khomeini, another incident challenged the Shah's regime. More than a thousand tullab, or clerical students, took over the Madraseh Faizieh Qom, the most important educational establishment for clerics. The time and place were obviously well chosen. The location was near the shrine of Fatima, a pilgrimage site for Shiite Moslems from all over the country. The protests were joined by clerical students from the Madraseh-e Khan, an adjacent school, and lasted for three consecutive days and nights. The rebels raised a red flag, symbol of Shite martyrdom, high enough to be seen throughout the city of Qom and began broadcasting tapes of Khomeini's fiery speeches against the Shah. When the uprising broke out, the government shut off the school's water and electricity. Police surrounded the school and attempted to rout the students with tear gas and high-pressure water hoses, but the protesters defended themselves with bricks and sticks. The rebellion was finally put down by several units of army commandos dispatched from Tehran. By the second day, more than five hundred students had been arrested, a few killed (Fischer, 1980), and many more injured. Following the insurrection's collapse, the Shah's secret police, the Savak, shut down the school, which remained closed throughout the rest of the Shah's rule.

Ayatollah Khomeini acted swiftly to endorse the students' cause. On the third day of the insurrection, he sent a message of condolence on behalf of the martyrs of the Madraseh Faizieh Qom, congratulating them and the Iranian people for their struggle against the Shah's dictatorship and the United States's imperialism. He mentioned that fortyfive had been killed and denounced the government's order to refuse the injured admission to Qom hospitals. The general public offered no support for the rebellious students, however. No strikes or bazaar shutdowns occurred anywhere in the country. The closing of the most im- 
portant clerical school in Qom precipitated no response by any social class. No national day of mourning was called to commemorate the deaths of the martyred students, nor was there any serious political condemnation of the government's actions except by Khomeini. These significant events seem to have gone completely unnoticed by the public.

The lack of action by bazaaris can be explained in terms of their economic interests and the economic prosperity brought about by the oil boom of 1973. Although some segments of the bazaar, including blacksmiths, coppersmiths, shoemakers, and moneylenders, had been adversely affected by state economic development policies, the oil boom created a unique occasion for many bazaaris to increase their assets. The sudden increase in national investment and consumption boosted domestic trade. The bazaar still controlled more than two-thirds of the domestic trade and more than 30 percent of the nation's imports. Hence, bazaaris in various sectors were in an advantageous position to benefit from the boom, and, as several bazaaris from Tehran and Tabriz have personally indicated to the author, a number undoubtedly improved their economic position.

\section{THE REVOLUTIONARY PERIOD, 1977-1979}

To understand the revolution of 1979 , we must examine the nature of the state, its development strategy, and the policies pursued by the government between 1975 and 1977. We must also investigate the capacities and resources for mobilization and collective action of each group within the opposition. Our analysis will focus on the struggles of bazaaris, industrial workers, white-collar employees, and professionals, who were the crucial actors in the overthrow of the monarchy. We will see that these groups and classes did not constitute homogeneous "communities" but instead were characterized by disparate interests, resources, and capacities for collective action.

State intervention in capital accumulation and economic development expanded following the 1963 reforms. Land reform undermined the power of the landed upper class and extended bureaucratic control over the rural social order. State economic centralization increased tremendously: the state soon owned oil, minerals, all modern manufacturing enterprises, most of the banking, insurance, transport, and communication firms, and a sizable number of farms and agribusinesses. In contrast, the entire private sector accounted for less than 20 percent of the national income by the end of Pahlavi rule (Katouzian, 1980). Finally, as the state expanded its bureaucracy and industrial assets, it became the country's largest employer, eventually employing approximately one-third of the urban labor force. Such intervention rendered the state vulnerable to challenge and attack. The government limited 
and replaced abstract market forces and thereby directly confronted all major social classes. As a result, in times of economic crisis the state, rather than the market, can be blamed and attacked.

Equally important was the nature of state development policies that adversely affected major segments of the population. The state consistently served the interests of the urban dominant class engaged in industry, banking, commerce, and agriculture at the expense of the vast majority of the population. Government development strategy and the oil boom intensified existing inequalities and led to uneven development (Pesaran, 1976; Halliday, 1978). State banking policies provided the small dominant class with cheap credit, while denying it to the middle and poor segments of the population. Import-substitution with high tariffs favored the growth of monopolies in the industrial sector at the expense of consumers. Industrial development was capital-intensive and restricted through limited licensing, thus preventing medium-sized capital from entering the most profitable sector. The capital-intensive nature of development adversely affected the working class by utilizing primarily skilled labor, which created a labor aristocracy. The pool of unskilled labor further expanded due to the government's neglect of agriculture and the consequent peasant migration. As a result, stratification within the labor force increased. Government taxation policies worsened the inequalities. The poorest 10 percent of the population paid 11 percent of their income in taxes, whereas the richest 10 percent paid only 8 percent in taxes (Kayhan, ${ }^{6} 1978$ : October 23). Many of the wealthy did not even bother to pay taxes.

In 1976, the government's oil revenues declined, forcing the regime to reduce expenditures, which resulted in economic recession. A major problem during this period was rising inflation, which the government attempted to check by controlling prices while lifting tariffs to increase imports. This price control policy had far-reaching consequences, for it led to a direct confrontation with the bazaar, initiating intense conflicts that culminated in the overthrow of the monarchy.

\section{Bazaaris and the State}

After 1975, the vast majority of bazaaris experienced economic pressures. Small artisans and shopkeepers in the carpet sector, for example, were adversely affected by inflation, which increased the price of raw materials and made Persian rugs less competitive on the worid market. In addition, lack of tariff protection and growing importation of machine-made carpets reduced the domestic sale of rugs. Government prohibition of child labor increased labor costs. As a result, many ba-

\footnotetext{
${ }^{6}$ Kayhan is an Irantan national newspaper. An international edition, cited later, is also published.
} 
zaaris in the rug business were forced to change to other sectors. In Ahvaz, capital of the oil-rich province of Khuzestan, thirty-six out of eighty shops selling Persian rugs closed down during the last nine months of 1977 (Kayhan, 1977: December 24).

With the economic crisis caused by declining oil revenues, the government imposed new demands on merchants. To balance the budget and finance unfinished projects, the regime imposed higher taxes on this class and reduced bank loans to shopkeepers (Ettelaat, 1977: August 23, 29). Toward the end of 1977, the state further extended its control by making shopkeepers' licenses contingent on two new conditions: first, merchants' guilds were required to guarantee that licensees would not violate the law; and second, landlords who rented space to shopkeepers were obiiged to write a formal letter of consent to the government on their behalf. These restrictions troubled some shopkeepers, for the guilds were unwilling to guarantee that licensees would not violate the law. Furthermore, bazaaris who disagreed with landlords over rents or other matters were automatically at a severe disadvantage (Ettelaat, 1977: December 3).

Of all the state's policies affecting shopkeepers, the most damaging were price controls and the "antiprofiteering campaign." In August 1975, the government rolled back prices of sixteen thousand items to their January 1974 levels. The profit rate was set at 14 percent even though inflation, according to the government's own reports, was at least twice that level. Prices were fixed at the retail market level where merchants and shopkeepers operated, but no controls were imposed on factories that produced and priced commodities, nor were restrictions placed on the small number of large importers. Throughout this uneven campaign, very few industrialists were arrested for violating price restrictions. Those who were prosecuted were often outsiders, such as Elghanian, a Jewish industrialist, or Habib Sabet, a Baha'i.

The impact of price controls on the bazaar was disastrous. In the first few days of the campaign, 7,750 shopkeepers were arrested (Kayhan International, 1975: August 8). By October 1977, approximately 109,800 Tehran shopkeepers, out of a total of 200,000 , had been investigated for price control violations (Ettelaat, 1977: October 27). According to the Ministry of the Interior, 20,000 shopkeepers had been jailed by the end of 1977 . By autumn 1978, the nationwide total of shopkeepers in violation of the controls was 220,000 (Ettelaat, 1978: September 26). The manner in which the regime carried out its campaign was humiliating. When special courts found a shopkeeper guilty, the shop was closed, a fine levied, and the shopkeeper subjected to imprisonment or exile. A large banner was hung from the doorway of the shop proclaiming that the store would be closed temporarily because the owner had been fined for profiteering. The courts also pub- 
lished names and localities of arrested merchants in national daily newspapers.

Prior to the government's antiprofiteering campaign and price control policy, there had been divisions within the bazaar. Economic development during the 1960 s and 1970 s had diversified the bazaar, and a number of successful merchants had left to deal in luxury goods. Because they benefited from state protection and limited licensing, they did not oppose the regime. Of those who remained in the bazaar, a wealthy minority supported the government. This was true even in the most traditional sector of the bazaar, namely, rug dealers. Bazaari organizations had also been undermined. Though some merchants and shopkeepers remained loyal to Mosaddegh's National Front, this organization had become practically nonexistent due to repression. The Merchants' Guild was controlled by the government and never gained the independence that the STBMSA had had. Religious bazaaris, too, were characterized by divergent political orientations. The upper echelon paid their religious taxes to Ayatollahs Shariat-Madari, Khonsari, and Khoie, while some middle- and lower-level shopkeepers paid taxes to Ayatollah Khomeini. ${ }^{7}$ These different religious leaders did not pursue the same political ends. Still other bazaaris backed the Freedom Movement, a liberal religious organization led by Mehdi Bazargan, a supporter of Mosaddegh. Some less prosperous shopkeepers and artisans supported the Islamic Mojahedeen, an organization with socialist leanings. The vast majority of shopkeepers nationwide, however, had become nonpolitical after years of repression.

These divisions indicate that no ideological consensus existed within the bazaar. The government's antiprofiteering campaign and price control policy, however, adversely affected most factions and impelled them to mobilize for collective action. Bazaaris already were geographically concentrated in specific centers across the country and possessed a national trading network that facilitated communication and mobilization for collective action. But they lacked an overarching, autonomous organization and a safe space to gather and organize their protests. Mosques and a segment of the clergy provided these key elements. It is important to note, however, that during this period, bazaaris began mobilizing independently of the mosque and long before the clergy. Initially, they supported secular opposition groups against the government. In Tehran, confrontation between the bazaar and the state began in spring 1977, following several months of antiprofiteering crackdowns and months before the massacre of clerical students in January 1978. Bazaaris began

\footnotetext{
${ }^{7}$ The leading supporters of Khomeini in the bazaar included Khamoushi, Pour-Ostad, Amani, Shafiee, and Asgar-Oladi.
} 
by supporting striking university professors who were protesting the government's decision to move their campus from Tehran to Isfahan. In retaliation, the government had cut faculty salaries. Bazaaris, along with university students, responded quickly by establishing funds to pay faculty salaries in full. In July, bazaaris denounced the Rastakhiz Party, the country's only political party, for "strangling" them through the price control campaign. By the end of summer 1977, representatives from Tehran's bazaar had met at least twice with officials of the Rastakhiz Party to express their dissatisfaction with the Chamber of Guilds, the government's credit policy, and the new taxation scheme (Ettelaat, 1977: August 23 and 29). In October, Tehran bazaaris illegally reestablished the STBMSA, which had been outlawed since the coup d'état of 1953 (Zamimeh-e Khabar Nameh, 16:31).

On November 15, 1977, an overnight sit-in occurred following a poetry night at which Saeed Soultanpour, a leftist poet, spoke of repression. The next day as students from the sit-in took their demonstration to the streets, nearby shopkeepers joined in and shouted anti-Shah slogans. After one student was killed during the protest, Tehran University students called for a national day of mourning on November 21 . The Tehran bazaar responded by shutting down completely to support the protest (Zamimeh-e Khabar Nameh, 8:12-13). The following day, three thousand bazaaris gathered in an orchard near Tehran to celebrate Aide Ghorban, a religious holiday, and invited leaders of the National Front. In reaction, the Savak dispatched 750 agents to break up the gathering, injuring many. This event illustrated the difficulties of mobilizing, and thereafter bazaaris increasingly turned to the mosque to organize their protests. In the following months bazaaris actively participated in the cycles of mourning ceremonies that began in Qom after the massacre of clerical students in January 1978. Bazaaris were able to finance mosque activities during these mourning ceremonies. In fall 1978 when Ayatollah Khomeini was expelled from Iraq, shopkeepers in more than a hundred cities went on strike. Significantly, no comparable action had taken place fourteen years earlier when Khomeini was initially exiled from his homeland.

Bazaaris supported Ayatollah Khomeini for several important reasons. Khomeini was the only religious or political leader who refused to compromise with the Shah, calling for his overthrow. Khomeini consistently condemned the Shah's dictatorial rule as well as the moral decadence and corruption of the Pahlavi dynasty. Throughout the revolutionary period, he promised political freedom to all social groups under an Islamic government. Khomeini also advocated social justice and maintained that an Islamic government would serve the Mostazafin, meaning the oppressed and the abased. Finally, Khomeini attacked im- 
perialist plundering of Iranian wealth. These statements were widely supported within the bazaar because they reflected bazaaris' central concerns.

\section{Industrial Workers and White-Collar Professional Employees}

Following the 1953 coup d'état, strikes were banned, and workers were prevented from forming independent labor organizations. Hit hard by repression and rising inflation in the 1970 s, workers responded with only a few wildcat strikes prior to the revolutionary period. Then the number of walkouts increased, from a mere handful between 1970 and 1973 to more than twenty in 1977 alone. During the first three months of 1978 , more than ten new strikes were called. In spring and summer 1978 , three strikes occurred, mainly over economic issues. These strikes were unrelated to each other and lacked any coordination.

In late August 1978, Shariff-Emani's administration announced reforms that promised to liberalize the political system but completely ignored workers' economic plight. As a consequence, less than a week after the new administration took office, strikes broke out across the country. Thousands of workers in auto, steel, oil, and railway went on strike, to be joined by the vast majority of workers in other sectors. Toward the end of September, white-collar employees joined the strikes. Like industrial workers, they had been repressed, lacked independent organizations, and were adversely affected by inflation. Government policies systematically favoring the bureaucratic bourgeoisie generated strife between lower and middle echelons of the bureaucracy and the state. By mid-October the vast majority of industrial workers and white-collar employees were on strike. All this took place in little over a month in a country where strikes were illegal.

An analysis of strikers' demands during this period reveals that, with the exception of a few groups such as teachers and students who demanded political freedom, the most important issues were economic, with job-related problems close behind. All strikers demanded increases in wages and salaries, while most also insisted on allowances or loans for housing expenses and medical insurance. Many complained of inequalities in wages and job classifications, especially where foreign workers were employed. Some protested arbitrary promotion rules and secret "rewards" by heads of bureaucracies. Strikers in oil, Isfahan Steel, a Central Alborz mine, a Zahedan railway, and Iran General Motors in Tehran pressed for the dismissal of corporate directors or heads of government offices. Others such as postal employees complained their rights had been violated for years.

To end the strikes, the government agreed to some demands relatively quickly. As the scale of strikes increased, the regime decided to 
deal with them on the national level and proceed with concessions, rather than repression. Thus the government announced that within six months, in two stages, the salary of government employees would be raised by 25 percent (Ettelaat, 1978: October 10). Twenty thousand government employees were promised housing loans (Ettelaat, 1978: October 15).

Workers' response varied. While some returned to work, others remained skeptical about government promises. Some strikers complained that although they had been on strike for days, authorities had not even investigated their grievances. Most strikers regarded the concessions as insufficient because they demanded 50 to 100 percent salary increases along with additional benefits (Tehran Journal, 1978: October 11). Concessions offered to industrial workers were not as favorable as those given white-collar workers. The latter were promised housing loans, while industrial workers were to be given low-rent housing by their employers who, in turn, were subsidized through government loans. This plan meant that workers would never own their houses and would therefore be even more dependent on their employers. Because of these inadequacies, major segments of the work force rejected the government's offer.

Toward the end of Shariff-Emami's administration, some strikers joined students and faculty in making political as well as economic demands. Employees of the Bank Melli of Iran struck for a second time, claiming that the government had not kept its promise to increase salaries and also demanding the release of all political prisoners and the dissolution of martial law. Striking oil workers and employees of Iran Air, announcing their solidarity with the popular struggles, demanded unconditional release of all political prisoners, dissolution of martial law, and expulsion of foreigners from their respective sectors.

In response, the Shah suspended reforms and returned to a course of repression. On November 6 , any possibility of compromise was precluded when General Azhari was appointed to head a "law and order" military government. Almost immediately, the army tried to force employees back to work by occupying all strategic installations, including oil fields and refineries, radio and television stations, and newspaper offices. Universities and high schools were closed down, and college campuses were surrounded by the armed forces. Initially, the military administration brought about some degree of order. The second oil workers' strike in the south was ended. Strikers in the Ministry of Post and Telegraph, the State Tobacco Monopoly, the Tabriz machine-tool factory, and Isfahan Steel were forced to resume work.

In the context of popular mobilization, the military could not repress the opposition for long. With the imposition of the military government, bazaaris in major cities went on strike and did not reopen their 
shops for several months. Their action disrupted trade throughout the country. In addition, the earlier protests and strikes by workers and whitecollar employees had created new solidarity structures that were not easily dissolved. Employees in the banks of Melli and Markazi pulled down statues of the Shah and organized rallies at their workplaces. Protesting university professors and students organized antimilitary sit-ins to demand the reopening of colleges and universities, which had been closed by students themselves since the beginning of the school year. Industrial workers at the Tehran Oil Refinery, Arak Auto, and Tabriz Tractor continued their strikes despite military rule. They were joined by the Tabriz lift-truck factory the day after the military assumed power. In late November, electrical workers regularly shut off electricity at 8:30 P.M. to prevent the broadcast of government news programs over radio and television. On December 2, oil workers in the south struck for the third time. Soon workers in the Bandar Abbas Steel Complex, Isfahan Steel, Kerman Copper and Coal mines, and on railways throughout the country walked out (Kayhan, 1979: January 11, 15). By mid-January, the Chamber of Commerce stated that 3.5 million workers, including 1.5 million industrial workers, were out of work (Kayhan, 1979: January 20) and demanding political change.

In this second round of strikes, political demands outweighed economic issues. In their calls for freedom, industrial workers and whitecollar employees acknowledged Ayatollah Khomeini's leadership. On December 31 , a central council composed of government ministries and organizations from the private sector was organized to coordinate the strikes. The coordinating council issued a statement formally recognizing Khomeini as leader of the people's "anti-imperialist, anti-autocratic" movement (Hambastegi, ${ }^{8} 9$ ). The council rejected any compromise with Bakhtiar, the Shah's last prime minister, who, they claimed, represented "imperialism and dictatorship" (Hambastegi, 10). Within the coordinating council, oil workers, led by militants, 35 percent of whom were avowedly Marxist (Washington Post, 1979: February 26), played a critical role by disrupting oil production, which cut government revenues and intensified the economic crisis.

\section{CONCLUSION}

This analysis demonstrates that models of social breakdown and social movement do not adequately explain the collective actions of the Iranian revolution. Contrary to the claims of these models, neither uprooted migrants, nor the new middle class, nor the legitimate authority of the clergy and Shite martyrdom were the main agents generating the

${ }^{8}$ Hambastegi was a newsletter published at Tehran University during the fall of 1978. 
conflicts of 1977-1979, although they played some roles at different points. This analysis focuses instead on the nature of the state, conflicts of interest, capacity and opportunity for collective action, and coalition formation. The state intervened in the economy, limiting the operation of the market. A high level of state intervention rendered the government vulnerable to challenge and attack in times of crisis and conflict. The state's development policies adversely affected the interests of major social classes: bazaaris, industrial workers, white-collar employees, and professionals. The government's antiprofiteering campaign generated an intense conflict between the state and the bazaar. Bazaari mobilization provided an opportunity for other groups, especially the proKhomeini clergy, to oppose the regime. Government reforms in fall 1978 promised political freedom and reduction of repression, which in turn provided an opportunity for industrial workers and white-collar employees to strike and demand change. These groups formed a coalition which, under the leadership of a faction of the clergy, eventually brought down the monarchy.

Despite claims by some observers that the Iranian revolution was an aberration from modern revolutions, these same factors and similar sets of events have operated to generate revolutionary conflicts elsewhere. The Russian revolution of 1917 and the Nicaraguan revolution of 1979 , for example, display significant similarities with the Iranian experience. The governments of both the Tsar and Somoza were highly interventionist, with policies that adversely affected the interests of major social classes. These classes formed a temporary coalition during a period of crisis and succeeded in bringing down the government. In terms of the nature of the state, its development policies, and the formation of coalitions among adversely affected classes, the Iranian revolution is not atypical of other revolutions in contemporary Third World countries.

\section{REFERENCES}

\section{Abrahamian, Ervand}

1982 Iran Between Two Revolutions, Princeton, NJ: Princeton University Press.

Akhavi, Shahrough

1980 Religion and Politics in Contemporary Iran. Albany: State University of New York Press.

1983 "The ideology and praxis of Shi'ism in the Iranian revolution." Comparative Studies in Society and History 25(2):195-221.

Arjomand, Said

1981 "Shi'ite Islam and the revolution in
Iran." Government and Opposition 16:293-316.

1986 "Iran's Islamic revolution in comparative perspective." World Politics 38:383-414.

Ashraf, Ahmad and Ali Banuazizi

1985 "The state, classes and modes of mobilization in the Iranian revolution." State, Culture and Society 1:340 .

Binder, Leonard

1962 Iran: Political Development in a Changing Society. Berkeley: University of California Press. 
Davies, James C.

1962 "Toward a theory of revolution." American Sociological Review 27:519.

Deutsch, Karl W.

1961 "Social mobilization and political development." American Political Science Review 50:493-514.

\section{The Freedom Movement}

1978 Dar Bareh-e Ghiam-e Hammaseh Afarin-e Qom Va Tabriz Va Digar Shahr Hayre Iran, Vol. L. Published by The Freedom Movement, place of publication unknown.

Fischer, Michael M. J.

1980 Iran: From Religious Dispute to Revolution. Cambridge, MA: Harvard University Press.

Green, Jerrold

1980 "Pseudoparticipation and countermobilization: Roots of the Iranian revolution." Iranian Studies 13:3153.

1986 "Countermobilization in the Iranian revolution." In Jack Goldstone (ed.), Revolutions: Theoretical, Comparative, and Historical Studies. San Diego, CA: Harcourt Brace Jovanovich.

Halliday, Fred

1978 "The economic contradictions." MERIP Reports 8:9-18.

Huntington, Samuel $P$.

1968 Political Order in Changing Societies. New Haven, CT: Yale University Press.

Jazani, Bizhan

1979 Tarh-e Jame-eh Shenasi Va Mabanie Stratezhy-e Jonbesh-e Enghelabi-e Khalgh-e Iran. Tehran: Maziar.

Johnson, Chalmers

1966 Revolutionary Change. Boston: Little, Brown.

Katouzian, Homa

1980 The Political Economy of Iran. New York: New York University Press.

Keddie, Nikki

1983 "The Iranian revolutions in comparative perspective." American Historical Review 88(3):579-598.

\section{Momayezi, Nasser}

1986 "Economic correlates of political vi- olence: The case of Iran." The Middle East Journal 40(1):68-81.

Nategh, Homa.

1982 "The clergy and democratic freedoms." Jahan; April 3.

The Organization of the Iranian

People's Fedayee Guerrillas

1978 Gozareshatie as Mobarezat-e Kharej as Mahtoodeh. Tehran: The Organization of the Iranian People's Fedayee Guerrillas

Parsa, Misagh

1985 "Economic development and political transformation: A comparative analysis of the United States, Russia, Nicaragua, and Iran." Theory and Society 14:623-675.

1986 "Class and religion in the Iranian revolution" Paper presented at the Annual Meetings of the American Sociological Association, New York, September.

Pesaran, H.

1976 "Income distribution and its major determinants in Iran." In Jane Jaccqz (ed.), Past, Present and Future. New York: Aspen Institute for Humanistic Studies.

Pipes, Daniel

1983 In the Path of God: Islam and Political Power. New York: Basic Books.

Saikal, Amin

1980 The Rise and Fall of the Shah. Princeton, NJ: Princeton University Press.

Sick, Gary

1985 All Fall Down. New York: Random House.

Skocpol, Theda

1979 States and Social Revolutions: A Comparative Analysis of France, Russia, and China. Cambridge: Cambridge University Press.

1982 "Rentier state and Shi'a Islam in the Iranian revolution." Theory and Society $11: 265-283$.

Smelser, Neil J.

1962 Theory of Collective Behavior. New York: The Free Press.

1966 "Mechanisms of change and adjustment to change." In Jason L. Finkle and Richard W. Gable (eds.), Polit- 
Theories of Collective Action

ical Development and Social Change. New York: John Wiley.

Stempel, John D.

1981 Inside the Iranian Revolution. Bloomington: Indiana University Press.

Tehranian, Majid

1980 "Communication and revolution in Iran: The passing of a paradigm." Iranian Studies 13:5-30.

Tilly, Charles

1978 From Mobilization to Revolution. Reading, MA: Addison-Wesley.
Willy, Charles, Louise Tilly, and Richard Tilly

1975 The Rebellious Century, 1830-1930. Cambridge, MA: Harvard University Press.

Walton, Thomas

1980 "Economic development and revolutionary upheavals in Iran." Cambridge Journal of Economics 4:271292.

Wilkinson, Paul

1971 Social Movement. New York: Praeger. 